\title{
Oceanographical Studies on Japanese Inlets (5), Relations betwecn Variation of Chemical Compositions and Hydrographic Conditions in Uranouchi Bay (Part 3)
}

\author{
Hiroshi Yamamoto
}

\begin{abstract}
The author has studied two of the chemical ingredients of inlet water, ca!cium and magnesium, and tried to see the variation they show according to the difference in characteristics of various inlets.

1. The chemical composition of inlet water is subject to variation according to the features of different inlets, and the variation is regular in each inlet.

2. In the water of such inlets as are noticeably diluted by land water, a great variation is caused by the difference in hydrographic conditions.

3. In stable and stagnant inlets, $\mathrm{Mg} / \mathrm{Cl}$ is more remarkable than $\mathrm{Ca} / \mathrm{Cl}$ as the indicator element of a water mass.

4. The chemical composition of sea water in inlets varies according to the chemical elements and the state of mixing of different water masses.
\end{abstract}

\section{1. 緒 震}

前報 ${ }^{(1)}$ までは陸水の混合が甚だ活潑に行われる ものと思われる内湾での測定結果について述べて きたが，陸水の流入が僅少であり，乙か子外海水 との直接的な混合が活潑でない内湾では, 主とし て降雨による稀釈と日照による蒸発が濃度の変動 に関しては大きな要因となるであろうと思われる が, 湾内での生物による消費, 堆積物としての沈 積状況，及びそれらから海水への溶出等の諸現象 も前報迄の内湾とは違つた様相を呈するものとみ られる. 従つてこの棣な内湾では安定した海水の 停滞状態でどのように各塩類の塩素比が変るもの であるかについて明らかにすることが出来ると考 えられる。

* 1958 年 7 月 30 日受理.

** 高知大学教育学部化学教室, Chemistry Institute, Faculty of Education, Kochi University.
われわれは比較的湾口が狭く，極端に入り込ん でいるために外海水の直接的な影響が少なく湖沼 的な性格を有するものとみられる浦之内湾に於い て第 3 報，4 報と同様にカルシウム及びマグネシ ウムの塩素比を測定して考察すると共に, 本報迄 に測定した種々な内湾のカルシウム及びマグネシ ウムの塩素比を比較することによつて総括的にそ の海洋化学的意味を研究し塩素比の変動が内湾の 特性によつて特意的であることを知つた.

\section{2. 浦之内湾の地形的概況}

本湾は宮地 ${ }^{(2)}$ 等の外多〈の研究者 ${ }^{(3)}$ によつて生 物学的見地から研究がなされその概況についても しばしば報告されているが，ここでもその概況を 述べる。

浦之内湾は東西に横たわる細長い半島によつて 外海と隔てられた内湾で面積は略々 $10.05 \mathrm{~km}^{2}$ と 


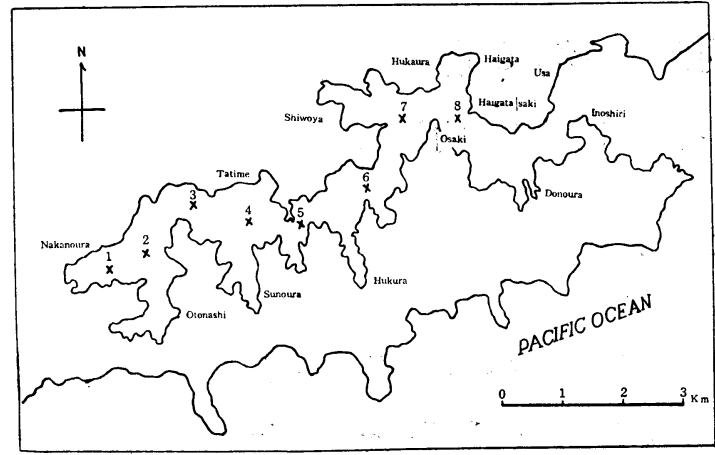

Fig. 1. Observational stations in Uranouchi Bay.

され, 井尻(INOSHIRI) から湾奥迄は延長約 $10 \mathrm{~km}$ である．周囲は山に囲まれ平地が少なく流入河川
は殆んどないため，河川による海水塩分の稀釈や 有機物流入による污染等は全くみられない。深度 は一般に湾口が浅く大崎から井尻にかけて干潮時 には干潟となる。中央部の深浦 (HUKURA), 立目 (TATIME) では $15 \mathrm{~m}$ でこれより次第に浅くなり 湾奥では $6 \mathrm{~m}$ 程度である。このように湾口が浅 いために, 大崎以東では潮流の影響が甚だ大きい。 湾内に深く入ると海水は殆んど停滞して，夏季に 顕著な成層がみられる，本湾の海洋条件としては 特に降雨の影響に注意しなければならない。

\section{3. 分析の結果とその考察}

1957年 6 月に湾内 14 点で採水した 70 の資料に ついてカルシウム及びマグネシウムの分析を行つ た．分析の方法は前報と同様である．分析の結果

Table 1

\begin{tabular}{|c|c|c|c|c|c|c|}
\hline St. Depth m. & Temp $\mathrm{C}^{\circ}$ & $\mathrm{Cl} \mathrm{g} / 1$ & $\begin{array}{c}\mathrm{Ca} \\
\mathrm{mg} \text {-atoms/1 }\end{array}$ & $\underset{\mathrm{mg} \text {-atoms/1 }}{\mathrm{Mg}}$ & $\mathrm{Ca} / \mathrm{Cl}$ & $\mathrm{Mg} / \mathrm{Cl}$ \\
\hline $\begin{array}{l}0 \\
1 \\
2 \\
3 \\
4 \\
5 \\
7\end{array}$ & $\begin{array}{l}28.3 \\
27.9 \\
26.3 \\
25.8 \\
25.6 \\
25.4 \\
24.6\end{array}$ & $\begin{array}{l}17.04 \\
17.57 \\
18.21 \\
18.38 \\
18.42 \\
18.45 \\
18.41\end{array}$ & $\begin{array}{l}9.31 \\
9.51 \\
9.80 \\
9.90 \\
9.92 \\
9.95 \\
9.91\end{array}$ & $\begin{array}{l}46.39 \\
48.09 \\
49.61 \\
49.93 \\
50.15 \\
50.18 \\
50.10\end{array}$ & $\begin{array}{l}0.02190 \\
0.02169 \\
0.02157 \\
0.02159 \\
0.02158 \\
0.02161 \\
0.02157\end{array}$ & $\begin{array}{l}0.06621 \\
0.06657 \\
0.06626 \\
0.06607 \\
0.06611 \\
0.06615 \\
0.06619\end{array}$ \\
\hline $\begin{array}{r}0 \\
1 \\
2 \\
4 \\
6 \\
8 \\
10\end{array}$ & $\begin{array}{l}28.2 \\
28.2 \\
26.3 \\
25.7 \\
25.4 \\
24.8 \\
24.4\end{array}$ & $\begin{array}{l}17.00 \\
17.14 \\
18.02 \\
18.41 \\
18.45 \\
18.45 \\
18.42\end{array}$ & $\begin{array}{l}9.25 \\
9.31 \\
9.79 \\
9.95 \\
9.97 \\
9.96 \\
9.99\end{array}$ & $\begin{array}{l}46.54 \\
47.03 \\
49.05 \\
50.06 \\
50.30 \\
50.23 \\
50.19\end{array}$ & $\begin{array}{l}0.02181 \\
0.02177 \\
0.02177 \\
0.02166 \\
0.02170 \\
0.02164 \\
0.02169\end{array}$ & $\begin{array}{l}0.06658 \\
0.06672 \\
0.06620 \\
0.06613 \\
0.06629 \\
0.06621 \\
0.06627\end{array}$ \\
\hline $\begin{array}{r}0 \\
1 \\
2 \\
6 \\
8 \\
10 \\
13\end{array}$ & $\begin{array}{l}27.9 \\
27.9 \\
27.7 \\
25.6 \\
25.1 \\
24.8 \\
24.2\end{array}$ & $\begin{array}{l}17.14 \\
17.40 \\
18.02 \\
18.52 \\
18.53 \\
18.57 \\
18.59\end{array}$ & $\begin{array}{r}9.30 \\
9.44 \\
9.72 \\
10.02 \\
9.97 \\
10.00 \\
10.04\end{array}$ & $\begin{array}{l}46.85 \\
47.62 \\
49.09 \\
50.33 \\
50.29 \\
50.41 \\
50.55\end{array}$ & $\begin{array}{l}0.02175 \\
0.02174 \\
0.02161 \\
0.02168 \\
0.02156 \\
0.02158 \\
0.02165\end{array}$ & $\begin{array}{l}0.06648 \\
0.06656 \\
0.06625 \\
0.06609 \\
0.06600 \\
0.06602 \\
0.06613\end{array}$ \\
\hline $\begin{array}{r}0 \\
1 \\
4 \\
6 \\
8 \\
10 \\
12 \\
15\end{array}$ & $\begin{array}{l}27.8 \\
27.7 \\
26.3 \\
26.0 \\
25.6 \\
25.0 \\
24.9 \\
24.1\end{array}$ & $\begin{array}{l}17.28 \\
17.38 \\
18.51 \\
18.59 \\
18.62 \\
18.61 \\
18,64 \\
18.61\end{array}$ & $\begin{array}{r}9.43 \\
9.46 \\
10.00 \\
10.06 \\
9.92 \\
9.99 \\
10.05 \\
10.04\end{array}$ & $\begin{array}{l}47.26 \\
47.47 \\
50.07 \\
50.59 \\
50.81 \\
50.59 \\
50.75 \\
50.67\end{array}$ & $\begin{array}{l}0.02187 \\
0.02182 \\
0.02165 \\
0.02170 \\
0.02135 \\
0.02144 \\
0.02161 \\
0.02166\end{array}$ & $\begin{array}{l}0.06652 \\
0.06643 \\
0.06679 \\
0.06625 \\
0.06638 \\
0.06612 \\
0.06621 \\
0.06622\end{array}$ \\
\hline $\begin{array}{r}0 \\
1 \\
2 \\
4 \\
6 \\
8 \\
10 \\
14 \\
19\end{array}$ & $\begin{array}{l}28.0 \\
27.5 \\
26.8 \\
26.4 \\
25.8 \\
25.8 \\
25.5 \\
24.5 \\
24.7\end{array}$ & $\begin{array}{l}17.49 \\
17.64 \\
18.24 \\
18.57 \\
18.64 \\
18.74 \\
18.76 \\
18.76 \\
18.86\end{array}$ & $\begin{array}{r}9.42 \\
9.55 \\
9.87 \\
10.00 \\
10.09 \\
10.12 \\
10.13 \\
10.13 \\
10.15\end{array}$ & $\begin{array}{l}47.85 \\
47.90 \\
49.81 \\
50.38 \\
50.80 \\
50.95 \\
50.88 \\
50.85 \\
51.19\end{array}$ & $\begin{array}{l}0.02159 \\
0.02170 \\
0.02169 \\
0.02158 \\
0.02170 \\
0.02164 \\
0.02164 \\
0.02164 \\
0.02164\end{array}$ & $\begin{array}{l}0.06654 \\
0.06604 \\
0.06641 \\
0.06598 \\
0.06627 \\
0.06612 \\
0.06596 \\
0.06592 \\
0.06601\end{array}$ \\
\hline
\end{tabular}




\begin{tabular}{cc|c|c|c|c|c|c}
\hline St. Depth & & Temp C & $\mathrm{Cl} g / 1$ & $\begin{array}{c}\mathrm{Ca} \\
\text { mg-atoms/l }\end{array}$ & $\begin{array}{c}\mathrm{Mg} \\
\mathrm{mg} \text {-atoms/l }\end{array}$ & $\mathrm{Ca} / \mathrm{Cl}$ & $\mathrm{Mg} / \mathrm{Cl}$ \\
\hline$[6]$ & 0 & 27.5 & 17.23 & 9.31 & 47.02 & 0.02166 & 0.06637 \\
& 1 & 27.6 & 17.83 & 9.62 & 48.76 & 0.02162 & 0.06650 \\
& 2 & 27.1 & 18.33 & 9.82 & 49.93 & 0.02145 & 0.06625 \\
& 4 & 26.4 & 18.64 & 10.02 & 50.71 & 0.02155 & 0.06616 \\
& 6 & 26.1 & 18.76 & 10.16 & 50.99 & 0.02171 & 0.06610 \\
& 15 & 25.1 & 18.83 & 10.13 & 51.17 & 0.02156 & 0.06609 \\
{$[7]$} & 18 & 25.2 & 18.99 & 10.16 & 51.46 & 0.02144 & 0.06591 \\
& 0 & 27.6 & 18.00 & 9.77 & 49.11 & 0.02175 & 0.06635 \\
& 1 & 27.0 & 18.45 & 9.99 & 50.23 & 0.02170 & 0.06621 \\
& 2 & 26.6 & 18.60 & 10.05 & 50.68 & 0.02166 & 0.06627 \\
& 8 & 26.3 & 18.69 & 10.11 & 50.65 & 0.02168 & 0.06591 \\
& 10 & 26.2 & 18.66 & 10.10 & 50.75 & 0.02169 & 0.06614 \\
& 13 & 26.0 & 18.74 & 10.10 & 50.81 & 0.02160 & 0.05594 \\
& 0 & 25.3 & 18.86 & 10.19 & 51.43 & 0.02166 & 0.06632 \\
& 26.3 & 18.64 & 10.03 & 50.93 & 0.02159 & 0.06645 \\
\hline
\end{tabular}

は第 1 表にあげた．本湾の塩素量は $17 \sim 19 \%$ の 範図にあるので塩素比の值も浦戸湾や須崎湾の如 く顕著な変動はみ゙られない。まずカルシウムの塩 素比についてみると各採水点共特異的な变化はみ られなく，全般的には塩素量 $17 \%$ 以上の場合を 比較すると, $\mathrm{Ca} / \mathrm{Cl}$ では浦戸湾, 須崎湾より僅か 飞高く, $\mathrm{Mg} / \mathrm{Cl}$ では僅かに低い結果を得た。こ の様に本湾に於けるカルシウムの塩素比が高いこ との原因は明らかではないが，停滞状態にある本 湾の性格からみて種々な状態でカルシウムが蓄積 されているためであるかも知れない。

マグネシゥムの塩素比については，浦戸湾や須 崎湾の如く塩素量に対応する塩素比の関係をみる と, 湾口と湾奥とでは変化のしかたが異るので, 全般的な傾向として論ずることは出来ない，それ 故，これを詳細にみるため各地点別に塩素量及び $\mathrm{Mg} / \mathrm{Cl}$ の垂直的变化を第 2 図に示した．即ち, 塩

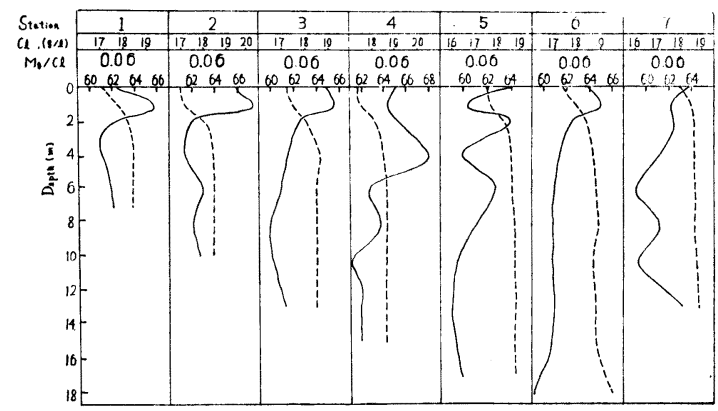

Fig. 2. Relation between chlorosity and $\mathrm{Mg} / \mathrm{Cl}$ at each station.

.... Chlorosity — $\mathrm{Mg} / \mathrm{Cl}$ (July, 1, 1957)

素量では各採水点共同様な傾向を示し，成層は 1 $\sim 2 \mathrm{~m}$ に形成している，これに対し $\mathrm{Mg} / \mathrm{Cl}$ は湾 奥附近と地点 6 では $1 \mathrm{~m}$ 附近で極大があらわれ, 漸時減少して或る深度で極小となり再び増加する 傾向を有する．この極小のあらわれる深度につい ては明らかな傾向はみられないが，水深と関係を 有するもののようにみ兄る，本湾に於ける海水の 循還範囲は現在迄の測定結果から湾口から深浦附 近までであると考えている，従つてこれより以西 の区域では殆んど停滞状態である.このことは $\mathrm{Mg} / \mathrm{Cl}$ の垂直分布にもあらわれていて，比較的 安定した水域では採水点 $1,2,3$ 点の如き分布を示 すが, 異水塊の混合と共にこの関係はくずれ $\mathrm{Mg}$ / $\mathrm{Cl}$ の分布も不規則になる傾向がある. 然しなが ら，或る程度混合が進んでくると地点 6 の如くに なり, 再び外海水との接触によつて $\mathrm{Mg} / \mathrm{Cl}$ の変 動が甚だしくなる. 即ち, 常に不安定な状態の水 域では $\mathrm{Mg} / \mathrm{Cl}$ の变動は不規則となる.

これらのことから，停滞状態にある内湾では， $\mathrm{Ca} / \mathrm{Cl}$ の变動よりはむしろ $\mathrm{Mg} / \mathrm{Cl}$ の变動の方が 水塊の指示要素として興味がある.

\section{4. 内湾の海況差による $\mathrm{Ca} / \mathrm{Cl}$ と $\mathrm{Mg} / \mathrm{Cl}$ の差異}

第 3 報，4 報及び本報での結果を総括的に以下 で考察する.

カルシウム及びマグネシウムと塩素量の関係は 外海水に近い $19 \mathrm{Cl} \%$ から陸水に近い極めて低 濃度の水に至るまで一つの直線上に分布すること については既に述べた通りである. 従つて, 同じ 海況下の海水では塩素量によつて概略的にカルシ 
ウム及びマグネシウムの量を求めることも出来る. 然し異つた海況下では海水の混合の過程を通じて カルシウム及びマグネシウムに消長の差異がある ためそれらがどのような変化をするかについては 塩素量に対応する塩素比をプロツトする方が便利 である. そのために組成の変動についての考察は 特別の場合を除いてこのような方法によつた.

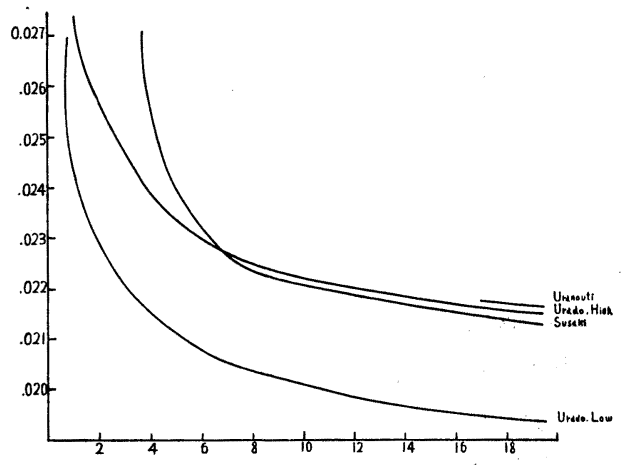

Fig. 3. Relation between chlorosity and $\mathrm{Ca} / \mathrm{Cl}$ in each inlet.

ここでカルシウム及びマグネシウムと塩素との 関係をそれぞれ近似的に一次式が成立つものとす れば，カルシウムに例をとると，

$$
\mathrm{Ca}=\mathrm{a} \cdot \mathrm{Cl}+\mathrm{b} \cdots \cdots \cdots \cdot(1) \text { となり }
$$$$
\text { 従つて } \mathrm{Ca} / \mathrm{Cl}=\mathrm{a}+\mathrm{b} / \mathrm{Cl} \cdots \cdots \text { (2) となる }
$$

$\mathrm{a}$ は海水中の塩素量及びカルシゥム量が変化す る場合の定数で, b は $\mathrm{Cl}$ 量が極めて小さい場合 に相当するカルシウム量であつて，この場合は河 川水中のカルシウム量と一致する.

従つて（2）式から明らかな如く, $\mathrm{Cl}$ が稀釈さ れてゆくに従つて $\mathrm{Ca} / \mathrm{Cl}$ の值は大となり,一つ の曲線上に分布する. 故に全く海水成分間に組成
の変動がみられなくともこのような曲線となり得 るが， b の值即も，流入河川水より供給されるカ ルシウム量の変化があれば当然のことながら $\mathrm{Ca} /$ $\mathrm{Cl}$ 曲線の形態が異なり須崎湾と浦戸湾を比較し た場合の如くになる.

もしも同じ塩素量に対してカルシウムの含量が 異るなどの組成上の変動があれば $\mathrm{a}$ の值が異るた めに $\mathrm{Ca} / \mathrm{Cl}$ の曲線はその高さを異にすることと なる．浦戸湾はこのように組成の大きな变動がみ られる. 然し第 3 報でも述べた様に 1 日の朝汐に 於てもこの曲線の示す值からはなれた值が得られ る筈であるが，現在までの測定ではそのよ5な測 定值は得られなく $a$ の值を異にする曲線上にすべ て分布されたためにこれらの曲線の移行は比較的 長い周期でかわるものであろう.

$\mathrm{Mg} / \mathrm{Cl}$ についてもカルシウムの場合と同様の ことが云える.ただ陸水からのマグネシウムの供 給が少ない上に海水中のマグネシウムが多いため か浦戸湾のカルシウムの如く海況差による顕著な 差異はみられなかつた.

終りに臨み本研究に御想篤な御指導を賜わつた 京都大学石橋雅義教授に深甚の謝意を表すると共 に御協力下さつた当教室の今井嘉彦氏に感謝の意 を表する。

\section{文献}

(1) 山本広志, 1958 :

“本邦内湾の海洋化学的研觉” 第 3-4 報 日本海洋学会誌, 14. 155 161.

(2) 宮地云三郎外, 1944 :

“浦之内湾飞於ける内湾度と潮間帯並び底 “棲郡聚との関係” 日本海洋学会誌, 3, 207

（3） 植田 穂, 1949 :

“浦之内湾の研究” 日本水産学会誌， 15 , 190. 